DOI: $10.1515 /$ hssr -2015-0016

HSS IV.2 (2015)

\title{
Of Masters, Men, Machines and (M)others: Revisiting the Virgin and the Dynamo in a Post/Trans-Human Context
}

Sorina Chiper *

Alexandru Ioan Cuza University of Iasi, Romania

\begin{abstract}
The Education of Henry Adams owes its cultural cachet, in part, to Adams' elaboration of a dichotomy that has pitted religion against science and technology. Though Western ideologies of modernity have viewed religion in rather negative terms, the current revival of religiosity in the postist context (post-modern, post-communist, post-colonial, post-human) invites a reconsideration of the role of religious belief, practice and objects/symbols in the current society. This article discusses Henry Adams's dichotomy of the Virgin and the Dynamo, and recontextualizes it from a post-human perspective. It argues that the return of religiosity or spirituality, in its multiple forms, is an ethical stance that signals a cultural need for the feminine values of care, solidarity, affection and affiliation.
\end{abstract}

Keywords

Henry Adams, Virgin, Dynamo, cultural object, trans/post-humanism

Faculty of Economics and Business Administration, Alexandru Ioan Cuza Unversity of Iasi, 22 Carol I Ave., 700198, Iasi; sorinachiper@gmail.com 


\section{Introduction}

At the dawn of the $20^{\text {th }}$ century, in 1907, Henry Adams - American writer and historian - privately published and circulated a hundred copies of his newly completed autobiography, The Education of Henry Adams. This work became widely available to the general public only with its posthumous publication in 1918, whereupon it won the celebrated Pulitzer Prize. A piece of broad intellectual ambitions ${ }^{1}$, The Education ... has enjoyed a long and successful afterlife, still ranking number one in Modern Library's top-100 best non-fiction book published in English (the Board's list) ${ }^{2}$. It is now part of the intangible American cultural capital that, in Lynn White's words, The Education ... "has helped to shape the notions and emotions of millions of Americans who have never even heard of it" (White, 1958: 183).

Its success comes, probably, from the fact that the book undertakes an impressive survey of the American society in the late $19^{\text {th }}$ century, offering a panoramic view of American politics, history of ideas and cultural developments. Very ambitious in what it proposes to achieve, namely to act as an intertext to Augustine's Confessions, to instruct ("to fit young men, in universities or elsewhere, to be men of the world"), and to study the relationship between individual history and History ("probably he was, in fact, trying only to work into it his favorite theory of history") (Adams, 1918: vii-viii), The Education... teaches by negatives and it focuses on Adams' sense of failure and keen consciousness of being a misfit in the modern American society. The notion of personal failure, however, should be taken with a pint of salt. Adams came from a family that gave the United States two Presidents; he was a historian teaching at Harvard; the author of two novels and of numerous press articles; a man that had the privilege to attend history-making events, to foresee changes and evolutions in geopolitics, to travel the world and learn from his experiences.

\section{The Education of Henry Adams and the Law of Genre}

Interestingly enough, the subtitle "An Autobiography" was not added by Adams himself but by his editor, Henry Cabot Lodge. If we were to judge it by Lejeune's definition of autobiography as a "retrospective prose narrative written by a real person concerning his or her own 
existence, where the focus is his individual life, in particular the story of his personality" (Lejeune, 1980: 4), and by Lejeune's additional comments that autobiography is characterized by the identity between the author, the narrator and the protagonist, The Education... obviously fails to meet the formalist criteria of the genre. However, Lejeune himself acknowledged it in On Autobiography as a deviant, yet exquisitely original case of autobiography.

Adams' technical choice to write about himself in the third person rather than in the first person narrative allowed him to deploy a fine irony directed at himself, as a warning against the dangers of the simple and trusting acceptance of tradition, of dilettantism, and the pursuit of reason and order. Schooled, like most people of his generation and like all people of his class, in the spirit of the $18^{\text {th }}$ century's overconfidence in order, economic progress, individual freedom and the appropriateness of classical philology to suit someone to live in the world, Adams leads a life of continuous learning and unlearning, hope and disbelief, intellectual enchantment and disenchantment.

Unlike traditional autobiographies where the emphasis is on personal developments and intimate dynamics, therefore on personal knowledge, The Education ... is an autobiography as historical knowledge. It retraces $19^{\text {th }}$ century attempts at explaining the world and it progresses from Adams' childhood impressions, perceptions and blurred memories to the elaboration of metatheories of history, of "large syntheses" on cultural symbols, international politics and the American mind.

Henry Adams was the distant witness of huge social transformations and historical events of long lasting effects in the American history, such as the secession war, political assassinations, the Spanish-American war, the exhibitions at the turn of the century, the spread of the railway system and banking reforms. Society and human character changed under Adams's eyes, just like his own guiding principles came to acquire different meanings, in the new capitalist, competition-driven environment. The autobiography emerged out of Adams' belief that "[e]very man with self-respect enough to become effective, if only as a machine, has had to account to himself for himself somehow, and to invent a formula of his own for his universe, if the standard formulas failed" (Adams, 1918: 472). Giving an account of himself turned, for 
Adams, into an account of his own age and of his generation; he extrapolated his personal experience and from his liminal position - as a privileged member of the social and political elite, he attempted to explain crises in American culture and politics, as well as in humanity.

As Lesser argued, Adams approached his text as an inquiry, as "an attempt to state those problems through which the world is made known to its inhabitants" (Lesser, 1982: 378). These problems capture the gist of human experience, since we know the conditions of possibility of our world, thought, language and action only through the hypotheses by which we, as a species, have approached them, historically. To the extent that Adams investigates the ideological conditions of our modus vivendi and modus operandi in the world - though "ours" encompasses only a West-European and North American perspective - The Education ... reveals itself as a "representation of thought, not merely as a combination of formal elements; it transcends literary and social laws and preconditions the author's discovery of principles" (Lesser, 1982: 378). Thus, following the almost existentialist track of this gnostic investigations, Adams avoids the limitations of classic disciplinary discourses and combines historical inquiry with ethics, aesthetics with anthropology, linguistic self-consciousness with theology, journalisticstyle political and economic analysis with subjective, personal memory.

The text is divided into two parts - the first twenty chapters covering the years 1838-1971 (the years of Adams' struggle to understand his role in his immediate surroundings and personal, family history and man's relation to the world and History) and the other fifteen chapters covering the years 1892-1905 (the chapters in which Adams' disappointments with the limitations of epistemology inform his attempts at explaining the world and man's position in it from the perspective of an assumed trans-historical consciousness).

\section{The master's lessons}

The Education... is a bitter critique of modern society where one's individual potential, though - in theory - free to express itself, becomes socially curtailed by the development of large corporations, the prioritization of material gains over spiritual ones, and the thwarting of stable, long-lasting human relations. 
From cradle to grave this problem of running order through chaos, direction through space, discipline through freedom, unity through multiplicity, has always been, and must be, the task of education, as it is the moral of religion, philosophy, science, art, politics and economy (Adams, 1918: 12). This sentence can rightfully be considered the thesis of The Education of Henry Adams.

In The Education..., freedom and order are defined by opposition with discipline and chaos. Adams searches for freedom of thought and freedom of expression, yet he meets with the newspapers' censorship of his ideas and refusal to publish his articles, or with the denial of the fulfillment of his social and political aspirations by the fact that his training and social background incapacitated him for the ever transforming and ever mercantile end of the $19^{\text {th }}$ century and beginning of the $20^{\text {th }}$ century America.

The notion of education functions as a metaphor for Adams' whole life of lessons in a negative key: for instance, Adams learns that formal, academic teaching - in the Berlin or Harvard style - could not enlighten one to understand human conduct; that power destroys human relations, leading to treason (e.g. Charles Sumner's treason of the cause of the Soil Party), corruption and chaos (under President Grant), and political assassinations, and that "every friend in power is a friend lost" (Adams, 1918: 248). But maybe more relevant than these practical lessons is the lesson about what and how one can learn, namely Adams' awareness of the limitations of any theory and hypothesis to explain the increasingly complex conditions and challenges of modern life, of the provisional character of any scientific method and of any intellectual explanatory model of the world. What one can know of the world is preconditioned by the interpretative lenses that one brings to the world; what one can know of one's self is preconditioned by one's preconceptualization of the self.

As Lesser aptly demonstrated, one of the key chapters in The Education ... is "Failure." It dwells on the inadequacy of the evolutionary paradigm to explain the structure of selfhood and the narrator's inability to give a unified, coherent and non-contradictory story of the development of Adams" personality. While pondering on these "failures", Adams finds a 
significant correlation between individual existence as a micro history and the macro history of the humanity: both originate in human thinking. Therefore, neither selfhood (identity or culture), nor history is to be understood as a natural object of inquiry but as "conceptual entities conditionally created by individual acts of mind... by which our thinking has recognized a reality known only by way of hypothetical configurations" (Lesser, 1982: 385).

Such configurations are articulated in language; as linguistic expressions, they imply a choice: one particular statement takes shape by negating, through its assertion, other possible statements. The paradox of one's life story and the paradox of historiography is that as narrative, life writing and history are grounded in choice and therefore in negativity. As a historian at Harvard, Adams struggled with the impossibility of giving an exhaustive account of past events; as a historian of his own life, he found it hard to explain the discontinuity between the success story of his ancestors and his own lack of success as a journalist/analyst.

Negation, in Lesser's interpretation, functions for Adams as a "precondition of historical consciousness" (Lesser, 1982: 388). The "obsession with history" and the "experience of negation" combine to constitute the undergirding configuration behind Adams' understanding of the world and his position as a "repository of the past, consciousness of the present and prophet of the future" (Lesser, 1982: 382). When the narrator states that education had done its "worst," that it failed and that Adams remains "submissive," he builds a discourse of double negatives that is best decoded within the figure of antiphrasis. The lost confidence in $19^{\text {th }}$ century education to prepare one for the challenges of the $20^{\text {th }}$ century prepares the grounds for new epistemological explanations. Education failed in that Adams no longer believes in its relevance; but it also allows him to create a new interpretative grid - a historiography that is aware of its limitations and of its organizing principles.

Enflamed, at first, by the evolutionist theory, though he admits being a "Darwinian for fun" (Adams, 1918: 232), Adams rejects this theory since he could see no trace of evolution in forms of human life, in architecture, in American society, politics or in human character. On the contrary, President Grant's policy of drift was an obvious involution 
from Lincoln's policy of freedom and social order, and it allowed the breaking down of moral standards and the fetishizing of money as power that may be misused, denying, through corruption, the principle of equal opportunities and freedom for all. Thus, a transhistoric perspective shows that the only thing that can be demonstrated is not progress, positive development or advance, but multifarious change.

As his education/life progresses, Adams steers away from an understanding of man as a being of moral responsibility, capable to be in control of his own destiny and to inhabit the world in a sustainable manner. By the time when he wrote The Education..., he had come to acknowledge not only the 'multiplicity' of forces present in the modern world but also the increase in the intensity and velocity of these forces, paralleled by man's growing inability to resist or master them. Adams began to see "lines of force all about him, where he had always seen lines of will" (Adams, 1918: 426), and based on this understanding of the world as governed by impersonal and impending forces, he developed a meta-narrative that would encompass and explain the past, the present and possibly the future in mechanical, dynamic terms:

In the early stages of progress, the forces to be assimilated were simple and easy to absorb, but, as the mind of man enlarged its range, it enlarged the field of complexity, and must continue to do so, even into chaos, until the reservoirs of sensuous and supersensuous energies are exhausted, or cease to affect him, or until he succumbs to their excess (Adams, 1918: 487).

The passage above comprises some of the key concepts in Adams' theory: progress, complexity, and energy. Progress is "the development and economy of Forces" (Adams, 1918: 476), of which man himself is one. But man is also a "feeble atom or molecule" - the "sum of the forces that attract him" (Adams, 1918: 476). As a force of nature, man's function was to "assimilate other forces as he assimilated food" (Adams, 1918: 477), and his brain was violently stimulated when Nature "opened to it the possibility of sharing infinite power in eternal life (Adams, 1918: 477). Man probed the nature of God and developed theories attempting to understand Him and his own relation to divinity. The notion of energy used in connection to God brings Adams' understanding of the 
nature of the divine close to the theology of the Fathers of the early Christian church. For Saint Basil the Great, for instance, the essence of God remains unknown to humans, who can only understand God through His workings, as energy ${ }^{3}$.

One of the pioneering scholars in the West who related developments in physics to the study of history, Adams attempted to demonstrate that there could be no stable equilibrium in a world where phenomena are irreversible and events subject to chance. World politics are explained also in terms of movement and inertia as significant sources of power, irrespective of whether he dealt with the fall of the Roman Empire and the rise of Christianity or with Russia and Japan in the $20^{\text {th }}$ century.

Modern politics - argues Adams - is no longer a struggle of men and moral principles but a struggle of new energies, of economic interests, of capitals and resources. Confronted with chaos in the American society, in the American character, in domestic and international politics, Adams reaches the conclusion that "Chaos was the law of nature; Order was the dream of man" (Adams, 1918: 451). Faced with a drifting America, Adams finds solace in the Christian philosophy of order. He believed that the rapid pace of scientific and technological development required new mental powers to contain the new supersensual forces, and metaphysics was necessary to explain them. Hence, Adams' elaboration of the dichotomy that pitted religion against science and technology.

\section{The Virgin and the Dynamo}

"This is the story of an education, and the person or persons who figure in it are supposed to have values only as educators or educated" (Adams, 1918: 36), insists Adams. In the name of this principle he leaves aside the twenty years of his marriage, which is all the more surprising if we consider this gap in light of Adams' appreciation of women. After his wife's suicide, Adams traveled extensively around the world. These travels were an escape from the American present, and they sharpened his mind to look into the past, and into the future, and to notice the chaotic transformations of the American character. In the late 1890's Adams witnessed how capitalism was outgrowing individualism, how the American work ethic, in Max Weber's terms, was being replaced by material emoluments. 
In the summer of 1895, Adams toured Normandy and the neighbouring regions: Amiens, Bayeaux, Coutances, Mont-Saint-Michel, Chartres in the company of Senator Henry Cabot Lodge and of his wife. These pilgrimages inspired Adams' meditation on the decline of the visibility and potency of the Virgin as a religious and cultural symbol, as well as his thoughts on the role and cultural visibility of American women ${ }^{4}$. French Catholic shrines brought homage to the Virgin as the greatest force in the Western world. Either as a symbol or as energy, the Virgin had attracted man's activities towards her more intensely than any other natural or supernatural entity: "The Woman had once been supreme; in France she still seemed potent, not merely as a sentiment, but as a force. Why was she unknown in America?” (Adams, 1918: 385).

Adams blames the American ignorance of feminine power on the ideological conditions informing the birth of the American nation. American mythology left little room for powerful female figures, such as Venus or the Virgin had been in Europe ${ }^{5}$. The Puritan version of Christianity that flourished at the dawn of the American nation denied the public expression of women's sexuality. Rather than conceptualizing it as regenerative fertility, Puritan politics of sin turned female sexuality into a matter of shame and denial. American art, like American language and education, were "sexless": in industrialist America, "Society regarded this victory over sex as its greatest triumph" (Adams, 1918: 385).

"The highest energy ever known to man, the creator of four fifths of his noblest art, exercising vastly more attraction over the human mind than all the stream engines and dynamos ever dreamed of' (Adams, 1918: 385), the Virgin as energy had remained unknown to the American mind. At best, American culture knew Her only as artistic representation - "only as reflected emotion, human expression, beauty, purity, taste, scarcely even as sympathy." As a cultural symbol, in America she had never enjoyed power as she had never been feared.

In his study of myths (Myths, Dreams and Mysteries: The Encounter Between Contemporary Faiths and Archaic Realities), Mircea Eliade argued that "the great mythological themes continue to repeat themselves in the obscure depth of the psyche.... It seems that a myth itself, as well as the symbols it brings into play, never quite disappears from the present world of the psyche; it only changes its aspect and disguises its operation" (quoted in 
Cox, 1971: 127). Though Puritan Christianity did not observe religious celebrations nor engage in the cult of saints, relics, or icons, the idea of a cultic veneration was transferred across the Atlantic and it found a new embodiment, not in religious symbols but in technology.

At one point in the autobiography Adams identifies himself as a "pilgrim of progress" on account of his visits to technological exhibitions at the turn of the century. The Chicago exhibition from 1893 was emblematic of the changes that America was going through and of the emergence of "powerhouses" - corporations that controlled the new forces: the railway, the dynamo, the Daimler engine... Chapter 25 in The Education ... - "The Dynamo and the Virgin" pits two manifestations of veneration against each other and it captures Adams' reflection on the sources, significances and workings of power - be it physical or symbolic.

At the dawn of the $20^{\text {th }}$ century, the dynamo acts as a moral force and its cultural role was equivalent to that of the Cross at the dawn of Christianity. Just as religion required a leap of faith in a wholeness and unity of forces that could not be seen except in artistic representations or in mystic visions, so technology operates in mysterious ways, that cannot be grasped or perceived through the normal human sensorium except in its effects. In the Dynamo room in the 1900 Paris exhibition, contemplating the 40-feet machines, Adams finds it hard to see connections between steam and electric power, or to visualise, with the naked eye, $\mathrm{x}$-rays or the make-up of the atom: "he had entered a supersensual world, in which he could measure nothing except by chance collisions of movements imperceptible to his senses..." (Adams, 1918: 382).

The force of attraction exerted by technology differs, however, in its qualities, from the power of the Virgin. Mysterious - "the power of innocent life, the power of spontaneity, the power of growth, of the infinite forms of life," fully present in medieval cathedrals" - the Virgin inspired, motivated and elevated the human mind to create and translate, in human forms, the harmony and unity of a God-governed cosmos; technology inspires and motivates as well, but in a way that approaches its mystery to monstrosity and potentially, to cacophony and catastrophe rather than to life-supporting harmony. 
Perricone discusses the dichotomy of the Virgin and the Dynamo in terms of the operations of magic. Magic has a preconceived end; it is "a means to a set end... Magical power is the power that binds together the ideal and the real; it is the means by which the ideal is continually fed by the real. As soon as the magic fails, as soon as the image is mere representation, and we know it, we are no longer seduced" (Perricone, 1991: 261-270). Once human mind is no longer susceptible to higher energies, the Virgin dies. Hence, in Perricone's view, magical power is more than the sustaining power of symbols; it also operates as a generative power, stimulating the production of new creations. The magic of the dynamo is bred by the "infinity" of innovative gadgets that it can produce, and that attract as forever multiplying stimuli. While the artefacts inspired by the Virgin integrate, those generated by the Dynamo dissipate.

Drawing on Durkheim's The Elementary Forms of Religious Life, Cox highlights the fact that symbols of the sacred are characterized by "a high degree of power and of ambiguity... a 'religious symbol' is defined not by its content but by its relative degree of cultural power (Cox, 1971: 130). Moving on to explore Paul Ricoeur's book Symbolism of Evil, Cox highlights the two axes along which religious symbols develop: bondage and extrication, and defilement and purification. Along these axes, religious symbols develop rituals and operate within narratives that explain man and human society at the nexus of broader cosmic meanings, thus functioning as myths. Some technologies, too, already function as sacred symbols, lending themselves to potential involvement in both rituals and myths.

Of the Virgin, Adams thinks in terms of fecundity; her strength and force come from her potential to breed life. In American culture, however, Puritanism reconceptualised femininity, taming sexuality and confining it to the private realm of the family; it taught women to be modest, humble and obedient, and thus prepared the ideological grounds for the birth of a nation ridden by the masculine values of competition, conquest and self-interest. While in a decadently feminized European culture the Virgin had become a symbol that had lost power, in America, masculine vitality had left almost no room for public appreciation of feminine values. 
As Howard Horwitz noted, "The Education ... seeks ... to know... God, unequivocally' (quoted in Fuller-Coursey, 2003: 123). Adams' premodern sensitivity and ontological desire for unity and order took him back to the $13^{\text {th }}$ century, "the point of history where man held the

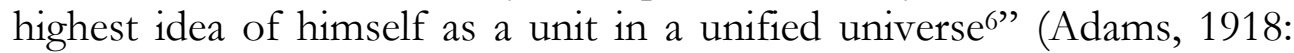
434-435). The cathedral of Mont Saint Michel and Chartres translated this idea of cosmic unity in its hymn in stone and glass dedicated to the Virgin. On his pilgrimages to medieval French cathedrals, Adams enters a dialogue with the Virgin and through Her, he attempts to know God as the Virgin and God are one.

The dialogue was dramatized in a poem (Prayer to the Virgin of Chartres) that Adams wrote and that was found in one of his wallets, after his death ${ }^{7}$. Standing, as an individual consciousness in front of the Virgin as a full partaker in the divine and as a co-redeemer, yet also assuming a cross-temporal perspective - the perspective of humanity as God's creation, Adams humbly remembers the days of medieval adoration, cathedral building and hymn singing. He confesses, as if on behalf of all humanity, that he has deserted the Mother in search for the Father's world and that he has created a realm of power without glory, where man put himself in God's place and worshiped the Dynamo.

And now we are the Father, with our brood,

Ruling the Infinite, not Three but One;

We made our world and saw that it was good;

Ourselves we worship, and we have no Son [...].

(http://teachingamericanhistory.org/library/document/prayer-to-the-virgin-of-chartres)

Yet this new faith in the affordances of a technology-ridden world contains the seeds of its self-destruction; in acting upon the environment, man put himself and his devices at the heart of his universe - in the position traditionally reserved for the sacred. To counter the effects of universal hubris at personal level, Adams turns to the Virgin and asks Her to help him have access to the boundless knowledge that comes from intimacy with God, rather than from the tools of reason. 
Help me to see! Not with my mimic sight -

With yours! Which carried radiance, like the sun,

Giving the rays you saw with - light in light -

Tying all suns and stars and worlds in one.

Help me to know! Not with my mocking art -

With you, who knew yourself unbound by laws;

Gave God your strength, your life, your sight, your heart,

And took from him the Thought that Is - the Cause.

Help me to feel! Not with my insect sense, -

With yours that felt all life alive in you;

Infinite heart beating at your expense;

Infinite passion breathing the breath you drew!

(source: http://teachingamericanhistory.org/library/document/prayer-to-the-virgin-of-chartres/).

In this prayer, Adams positions himself as a seeker of knowledge, who has witnessed the appeal to technology in acts of veneration (The Prayer to the Virgin at Chartres includes a prayer to the Dynamo), and laments the modern world's displaced religiosity (from transhistorical sacredness to contingent man-made breakthroughs in science and technology) not in terms of their social and institutional consequences but in terms of ontology and epistemology. Whereas the passion for freedom and order are naturally human and elevating, it is not in the emerging consumerist society, nor in the mechanical rule of the Dynamo, but in the openness to the mystery of creation that Man can fulfill his higher aspirations and accomplish his humanity. Science will always offer partial truths and temporarily valid theories. The only infallible source of truth, order and freedom is the Virgin as an unfathomable gate to the sea of knowledge about human character, the world and the divine, approached and revered in their mystery, and dis-covered in their fullness, in acts of revelation, rather than in painstaking scientific methods proceeding by trial and error.

The lesson of the Master, then, is that the ultimate freedom is that of the Virgin - that is, the freedom of the Spirit - and that the ultimate order is that which the church preached. But at the time when he was writing, Adams rightly intimated that the $20^{\text {th }}$ century was losing contact 
with the spiritual universe, with the mysteries and the irrational forces of creation and inspiration, preferring to invest its energy in the horizontal level of buildings, corporations, railways and mass communication. The paradox is that while the modern man pursues a dream of unity and freedom, the unity he discovers is that of multiplicity, and the freedom he seeks eludes him, being controlled by forces greater than himself: the market, political interests, and technology. Too much reasoning and too much acceleration in the pace of changing human living conditions are disastrous, implies Adams, and the empire of reason is bound to lead to catastrophe. Return to the values of motherhood - to love and care -, and to an acceptance of the mystery of Mary's dual ontological state, as mother and virgin, is the remedy that Adams implicitly recommends to heal the wounds of the modern disconnected soul.

\section{The Virgin and the Dynamo in a postist context}

Reading Adams one hundred years after he published The Education..., I am tempted to ventriloquise him and shudder in front of genetic engineering, nanotechnologies and the various ways in which technology and art are changing our perception of the human. In his prayer to the Virgin, Adams was bemoaning the overconfidence in man's capacity to alter our immediate environment, in perpetual progress and in an anthropocentric way of inhabiting the world. If he were to write now, he would probably point the finger at our global society's challenges: terrorism, biochemical guns, induced earthquakes, climate change, ecological disasters, the prospect of a sixth mass extinction ${ }^{8}$, and so on...

In Coleb Smith's view. "Adams was driven by the dynamo from oldfashioned humanism towards something very close to a posthumanist view of man and technology in an integrated matrix - he saw 'man' and his technologies embedded in patterns of impersonal 'force,' navigating circuits and flows" (Smith, 2008). However posthumanism implies more than the coterminous imbrication of man and machine; it also implies an ideological stance and ethical choices.

$20^{\text {th }}$ century literature often represented the modern condition in terms of human powerlessness to control the circumstances of our existence. Cox identified four symbolic solutions to entrapment and bondage: escape - by exerting one's energy; resignation - dignified 
acceptance of bondage; extrication - being saved by a power greater than oneself, and struggle against conditions that impose bondage (Cox, 1971: 132). Of the four, extrication seems to best capture the role of technology today, not just in the USA - as Cox had intimated - but anywhere in the globe. To give just one example, in June 2015, globalmedia reported the case of a Thai family who decided to freeze their daughter Einz's head, in the hope that in a few years, technology will be make it possible to connect her brain to a robot, thus allowing it/her to enjoy a second life. ${ }^{9}$ The affordances of technology - technopower, in Cox's terms - appear, in this futuristic (and plausible) scenario as a deux ex machina that will deliver Einz's mind from the confines of what we now consider to be death.

Originated in the 1960's, the practice of cryonics (and its ensuing rituals) is yet another instance of the modern recycling of age-old myths. Defeating death - "the most unknown of unknowns" (Levinas, 1999: 153) - has been a dream that humanity has shared in both myth and messianic religions. Christianity posits the immortality of the soul which, after the death of the body and after Judgment Day, will enjoy eternal bliss or eternal damnation. Eternal bliss depends on good deeds, on acts of charity, chastity and faith, in other words on intimate and public virtue. More or less modern myths usually condition the attainment of immortality as well. In the Romanian tale Youth without Age and Life without Death, blissful immortality, when attained, is maintained only by an act of virtue: the observance of an interdiction to cross over into the Valley of Weeping.

But virtue has nothing to do now with the choice of who is going to be frozen, de-frozen, wired into computers or assisted to live beyond the current life span. The cryonics ritual is grounded in an understanding of man as machine ${ }^{10}$ - and machines do not have virtue. Rather, such choices have to do with massive available capital.

Immortality has been turning into a successful business venture, with software magnates pulling together resources to make it available on an exclusivist market. In 2011, Russian mogul Dimitri Itskov set up the 2045 Strategic Social Initiative which, in its Manifesto, pleads for the achievement of the technical capabilities that will go beyond the current use of technology to alter / (arguably) improve human environment and 
bring it to act upon human life itself, altering it to the point of immortality:

We believe that it is possible and necessary to eliminate aging and even death, and to overcome the fundamental limits of the physical and mental capabilities currently set by the restrictions of the physical body (http://2045.com/about/).

The Initiative resonates with Donna Haraway's Cyborg Manifesto and her thesis that our world has been transformed by technology to such an extent that the defining oppositions implied by humanism, since Descartes (i.e. the difference between mind and body, human and animal, what is natural and what is artificial, what is physical and what is non-physical) no longer hold (Haraway, 2000: 293-294). In her argument, by the end of the $20^{\text {th }}$ century - "a mythic time" - we had all already become cyborgs - "theorized and fabricated hybrids of machine and organism... the awful apocalyptic telos of the 'West's escalating dominations of abstract individuation, an ultimate self untied at last from all dependency, a man in space" (Haraway, 2000: 292). The imperfect symbiosis between man and machine foregrounds their difference in terms of velocity and mass; the dynamo has been shrinking to the size of microchips, has reduced its noise to silence and its mass to almost nothing: "Our machines are disturbingly lively, and we ourselves frighteningly inert.... our best machines are made of sunshine; they are all light and clean because they are nothing but signals, electromagnetic waves, a section of the spectrum, and these machines are eminently portable, mobile... People are nowhere near so fluid, being both material and opaque" (Haraway, 2000: 294).

That the body is obsolete - a heavy mass that hosts human consciousness - has been the visual message of artistic projects such as Stelarc's Suspensions. For the past 13 years, the Greek-born Australian artist has displayed his naked body hanging from hooks, as inert mass, either static or moved by a remote control operated by Stelarc himself; he has experimented with the extension of the affordances of his body by connecting to it a prosthetic third arm, or by wiring it to a spider-like walking machine, or he has had a third ear cloned from his own body 
and surgically implanted on his left arm. This ear had sound-detectors and it was connected to a computer, so that anyone who wished to hear the sounds captured in the locale where Stelarc's reengineered body was situated could do so by accessing a website. Such experiments with fractal flesh and phantom flesh are meant, in Stelarc's view, to drive more forcefully the idea of a need for a human body that would be internet-enabled in more intimate ways (http://stelarc.org/?catID $=20242$ ).

The 2045 Initiative aims precisely to devise the solution that would eliminate the inertia of the human body, or its inefficiency as a sensing or reacting organism. Yet its envisioned design of the prototype of an artificial body onto which human consciousness would be transferred starts from the dangerous implied hypothesis that the human species as we know it is undergoing impending destruction anyway; hence, the need of a new body that would be immune to what is now destroying our current organic body: extreme temperatures or pressure, radiation, lack of oxygen. In the Initiative's strategy, it is not only that the fantasized post-2045 transhumans would exist as software, but also digitalised consciousness would be projected in several avatars, that could be remotely controlled. Thus, one consciousness could share several avatar bodies in various locations.

Seen from the perspective of the actually existing risks that endanger our planet and life as we know it - both ours and the life of plants and animals - such projects that would perfect/create (post)humans capable of withstanding the extreme conditions that now endanger humans seem like the private game of a select band of rich and spoiled children who would not grow up, engaging in an exclusivist play at God. As Adams had intimated, humanity cannot progress ad infinitum - reckless acceleration can lead to the accident of self-destruction.

The title of Alistair MacIntyre's 1984 book suggests another "post"label for our times: post-modernism and post/trans-humanism situate us in a post-virtue context - where morality is grounded neither in religion nor in universal human rights. As Paul Virilio had noticed, the acceleration of life and work effected by technological advances impacts mostly the disenfranchised, creating a world in which "the animal body of the worker is devalued as the bodies of other domestic species were 
before him" (quoted in Smith, 2004). What is more, as science fiction cinema has already shown, a post-human future could ignore human rights in the name of capitalist interests, and invest in the production of disposable organisms that are less than human ("life that does not deserve to live" - in Agamben's reworking of Binding's original formula (Agamben, 1998: 80-83), to be used for the re-engineering of an elite of super-humans. ${ }^{11}$

In How We Became Posthuman. Virtual Bodies in Cybernetics, Literature, and Informatics, N. Katherine Hayles critiques posthumanism precisely on account of its treatment of human life as bare life, of the devaluation of human embodiment as the very ground from which, in her perspective, any politics of resistance can begin. For both her and Virilio, technology is involved in the theoretical design and material production of persons who "retain their natural life for a period of time but have lost (or never had) claim to the more abstract subjectivity that would secure full membership in the community of the human. Women, long imagined to be the bearers of the burden of embodiment, are especially vulnerable to this exposure. Taken to an extreme, such a passage beyond "humanity" leaves the living and dying body behind as an object of experiment, even of extermination" (Smith, 2008).

Critics of posthumanism such as N. Katherine Hayles, as well as scientists who have become more vocal in signaling impending global environmental disasters, write with a sense of emergency and yet with the slim hope that the current state of exception can be reversed, that a moderate and appropriate attitude towards the human habitat and towards our proximate or more distant neighbours (both in space and hopefully, in a future time) can decelerate the race towards unthinking self-destruction.

\section{By way of conclusion: The return of the Virgin}

In such times of ontological, ecological and ethical crises, preserving and fostering life begs for a domestication of the affordances of the new dynamos by a return to the feminine values of the Virgin. To a certain extent, the revalorization of the feminine is already underway, and modernity's disdain for the premodern gives way not only in various forms of religious revival in the post-communist context or in the 
sprawling of alternative spiritual practices as a matter of liberal choice, but also in the appeal to alternative forms of healing, in the revalorization of age-old traditions, and the re-visitation of premodern perceptions of the cosmos in light of relativity theory, quantum physics, or general systems theory. Yet more needs to be done.

It does not fall within the scope of this article to preach, nor to elaborate a new ethics for the recovery of virtues in a postist context. Yet I would venture point out the alternative of a female ethics of care, respect, affection, and humility in how we engage the world and our fellows. Writing from a Christian Orthodox perspective, Paul Evdokimov argued that through their religious nature, women can effect a living integration - the only act that can resist the demolition and dehumanization carried out by the modern masculine culture (Evdokimov, 2004: 185). Feminism - argues Evdokimov - stripped women of their symbolic veil, encouraged them to fill the ranks of the working class, but also made them forget their vocation as entities whose modus vivendi is defined by the verb to be, rather than by the verb to do. As beings that exist by situating themselves, ontologically, in the sea of Being, women have an unmediated connection with the Spirit. They exist in harmony with universal order - bearers of the mysteries of Being.

The cultural revaluation of feminine values would not only instill more concern for the environment and the human or animal "others," but also approach the world in an attitude of reverence, which would accept that what is technologically possible is not always right, or useful, that the immediate gratification of desires is not necessarily good, and that sometimes, one can only gain by losing or by sacrificing. Internalizing the female value of sacrifice in how we relate to the world would reposition our existence in a long-term perspective - which is not the perspective of godless, avatar-mediated immortality (a form of monstrous living death) - but that of a responsible attitude towards what is human and organic in life, towards the preservation, rather than the radical alteration of both life and of the conditions that sustain it.

The posited cultural revaluation would also create the conditions of possibility for higher solidarity at a global level - as a prerequisite for the success of concentrated efforts to tackle global crises - a solidarity that would not be based on identity politics but on the recognition of 
affiliation: humans as sons and daughters, able to align themselves to either masculine or feminine values, but deliberately choosing to actualize the feminine values of care and nurture.

\section{References}

Agamben, G. Homo Sacer. Sovereign Power and Bare Life. Stanford University Press, 1998.

Adams, Henry The Education of Henry Adams. An Autobiography. Boston, New York: Houghton Mifflin Company, 1918.

Adams, H. Prayer to the Virgin at Chartres, available online at http://teachingamericanhistory.org/library/document/prayer-to-the-virginof-chartres/, accessed on 04 June 2014.

Cox, H. "The Virgin and the Dynamo Revisited: An Essay on the Symbolism of Technology" in Soundings: An Interdisciplinary Journal, Vol. 54, No. 2, 1971, 125-146

Evdokimov, P. Femeia si mantuirea lumii, 2004. Bucuresti: Christiana.

"Henry Adams, scientific historian: 'even into chaos "" in European Journal of American Culture, 2003, vol. 22, issue 2, 103-124.

Haraway, D. "A Cyborg Manifesto. Science, technology and socialist-feminism in the late twentieth century" in Bell, David, Kennedy, Barbara M. (eds) The Cybercultures Reader London, New York: Routledge, 2000, 291-324

Lejeune, Ph., "The Autobiographical Pact" in Eakin, Paul John (Ed.) On Autobiography. Minneapolis: University of Minnesota Press, 1989, 3-30.

Lesser, W. "Criticism, Literary History and the Paradigm: The Education of Henry Adams" in PMLA vol. 97 no. 3, May 1982, 378-394.

Levenson, J.C. The Mind and Art of Henry Adams, Stanford University Press, Stanford California, $2^{\text {nd }}$ edition, 1968.

Levinas, E. Alterity and Transcendence. London: The Athlone Press, 1999.

Perricone, Ch. "The Powers of Art: Reflections on "The Dynamo and the Virgin" in The Journal of Speculative Philosophy. Vol. 5, no. 4, Penn State University Press, 1991, 256-275.

Pinsker, S. "Henry Adams at Ground Zero" in The Virginia Quarterly Review. A National Journal of Literature and Discussion, Spring 2002, vol. 78 no. 2, 189-198

Smith, C. "Bodies electric: gender, technology, and the limits of the human, circa 1900" in Mosaic (Winnipeg). 41.2 (June 2008), 111+ . Literature Resource Center, University of Manitoba, available online at http://go.galegroup.com/ps/i.do?id=GALE $\% 7 C A 235281136 \& v=2.1 \& u=$ 
$\mathrm{dkb \& it}=\mathrm{r} \& \mathrm{p}=\mathrm{LitRC \& sw}=\mathrm{w} \&$ asid $=0883573 \mathrm{~d} 0381453 \mathrm{f} 6 \mathrm{~d} 560 \mathrm{~b} 4806 \mathrm{ad} 0 \mathrm{e} 27$, accessed 12 June 2015

Spretnak, C. Missing Mary: The Queen of Heaven and Her Re-Emergence in the Modern Church. Gordonsville: Palgrave Macmillan, 2005.

Vetter-Becker, P. "Sacagawea and Son: The Visual Construction of America's Maternal Feminine" in American Studies. Vol. 50, No 1 / 2, Spring/Summer 2009, 27-50.

White, L. JR "Dynamo and Virgin Reconsidered" in The American Scholar, Vol. 27, no. 2 (Spring, 1958), 183-194.

Winn, P. "Thai parents cryonically freeze toddler in hopes she may live again" in USA Today. Global Post, 05 June 2015, available online at http:/ /www.usatoday.com/story/news/world/2015/06/05/globalpost-thaiparents-freeze-toddler/28533905/, accessed on 14 June 2015.

*** International Manifestor of the "20145" Strategic Social Initiative, available online at http://2045.com/about/, accessed on 13 June 2015.

Websites:

stelarc.org

${ }^{1}$ Not since the days when the Puritan mind of Jonathan Edwards tried to reconcile determinism with free will has there been such a dazzling display of intellectual sophistication as there is in Adam's Education (Pinsker 2002:191). ${ }^{2}$ http://www.modernlibrary.com/top-100/100-best-nonfiction/, accessed on 14 June 2015

${ }^{3}$ The conceptualization of God as energy was taken a step further through St Gregory of Palama's dogma of God's uncreated energies, in the $14^{\text {th }}$ century.

${ }^{4}$ To blame technology only for the mitigation of the Virgin's role in Europe is a lopsided view. As Charlene Spretnak demonstrated in her book on the cult of the Virgin Mary in the Catholic church, changes in patterns of veneration, issuing from changes in the Church's dogma on Mary, took effect in modern times due to the Church's own agenda to contribute to the ideological and practical conditions that would make the oeacumenical union of Christian churches possible. Since the mid 1960's, i.e. since the Second Vatican council, the 'cult of the Virgin' has been replaced by "a more reasonable and scaleddown focus on the ordinary woman mentioned a few times in the gospels (Spretnak, 2005: 29). Adams related to the glorified, cosmological version of Mary, which inspired the cultural flowering in medieval art and religion; the ideological currents that came after - Renaissance humanism, Reformation, Scientific Revolution, Enlightenment - were not favorably disposed towards 
Mary. For more details on the cult of the Virgin, see Charlene Spretnak's Missing Mary: The Queen of Heaven and Her Re-Emergence in the Modern Church.

${ }^{5}$ One amendment begs to be made here. Adams is right in lamenting the absence of strong female figures in American culture before the early $20^{\text {th }}$ century. Yet an exemplary female figure did emerge precisely in the last years of Adams' life: Sacagawea, the Shoshone teenager who accompanied, as a captive, the Lewis and Clark Expedition from what is now North Dakota to the Pacific Ocean. Her first statue was erected as early as 1910, and throughout the $20^{\text {th }}$ century, her status became almost similar to that of a female saint in medieval Europe. For a discussion of her cultural canonization, see Patricia Vetter-Becker's "Sacagawea and Son: The Visual Construction of America's Maternal Feminine."

${ }^{6}$ Adams' yearning for unity was expressed not only by his passion for medieval architecture but also by his interest in French medieval music. Adams is remembered, even today, for bringing French medieval music to life in the United States (Fuller-Coursey, 2003: 107). He himself had been introduced to it by Miss Aileen Tone, whom he had hired as a companion after he suffered from a stroke.

7 Adams had also explored the frictions between religion and science in his earlier novels: Esther (1884) and Mont-Saint-Michel and Chartres (1907), to which The Education ... was intended as a sequel.

8 In a research article published in June 2015 by Science Advances, an international team of researchers from Berkeley, Stanford, Yale, University of Florida and Universidad Nacional Autónoma de México warned against the current, unprecedented high species extinction rate, which signals that a sixth mass destruction of the biota is already under way (For more information, see http://advances.sciencemag.org/content/1/5/e1400253.full)

9 Apparently, the parents themselves would like to resort to cryonics in the hope of living beyond death. According to USA Today, which reported this piece of news on the $5^{\text {th }}$ of June 2015, about 300 people are cryonically preserved at various facilities and more than 1,000 have made post-death cryonics arrangements. Interestingly enough, it was modern fertilization technology that made it possible for Einz to be born in the first place, by a surrogate mother.

http://www.usatoday.com/story/news/world/2015/06/05/globalpost-thaiparents-freeze-toddler $/ 28533905 /$, accessed on the $14^{\text {th }}$ of June 2015

${ }^{10}$ There is a long tradition of conceptualizing man in mechanical terms, since Descartes' times, when the comparison between men and machines went so far as to construct life-size replicas of people. In the $18^{\text {th }}$ century, with Julien 
La Metterie's L'Homme Machine (1747) and in the $19^{\text {th }}$ century, with the development of industrialism, there were heightened fears of overstandardization and mechanization of human life, potentially leading to something worse than death in the Christian tradition, namely the loss of one's soul.

${ }^{11}$ See, for instance, Michael Bay's 2005 science fiction thriller The Island, in which the main characters are human clones living in an underground facility until their turn has come to have certain organs harvested and transplanted into the humans who had paid for the creation of the clones.

\section{Biographical note}

Sorina Chiper is a lecturer of English for Business in the Faculty of Economics and Business Administration, the "Alexandru Ioan Cuza" University of Iasi. She holds a PhD in American Literature, an MA in American Studies and an MA in International Business. Her academic interests cover several research areas, from American autobiography in the $20^{\text {th }}$ century, intercultural communication and sociolinguistics to Translation Studies, anthropology, LSP teaching methodology and recent Romanian literature written in Israel. Throughout the years, she has conducted research in prestigious universities such as Hebrew University of Jerusalem (2014), University of Graz (20102011), Konstanz University (2010), Institute of Education (London, 2009), Copenhagen Business School (2009), University of California at Berkeley (2005-2006), and University of Copenhagen (2001). She has authored numerous articles published in international and national journals and she has co-authored three books of practical exercises in English for students of Economics. 